\title{
Protecting mammal diversity: opportunities and constraints for pragmatic conservation management in Cat Tien National Park, Vietnam
}

\author{
Gert Polet and Stephen Ling
}

\begin{abstract}
A case study is given of a conservation management planning exercise underway in Cat Tien National Park and its surrounding areas in southern Vietnam. The importance of reliable information in this process is demonstrated using the Park's mammalian diversity. Opportunities and constraints to engage the local communities in conservation management planning and implementation are reviewed. The spatial element in protected area management planning is stressed; in some areas strict preservation management regimes are needed to conserve critical biodiversity values while in other areas conservation benefits could be gained from engaging local communities in resource management. Pragmatic conservation management
\end{abstract}

planning decisions address identified threats, to be resolved by re-demarcation of boundaries, resettlement of people, and community-based conservation initiatives. These should result in a more viable Park as well as provide more secure livelihood conditions for the people elsewhere. This case study is put in the context of the wider conservation management debate.

Keywords Cat Tien National Park, community-based conservation, conservation management, mammalian biodiversity, protected areas, Vietnam.

This paper contains supplementary material that can only be found online at http:/ /journals.cambridge.org

\section{Introduction}

Over the past decade conservation practice in developing countries has been revolutionized by a suite of ideas concerning people living in and around protected areas (Wells et al., 1992; Borrini-Feyerabend, 1997; Spinage, 1998; Indamar et al., 1999; Roe et al., 2000; Adams \& Hulme, 2001). Traditionally, protected area management concentrated on preservation of biodiversity values by a responsible authority forbidding community involvement in decision-making and benefit sharing. This approach has been typified as the 'fences and fines' approach (Leader-Williams \& Albon, 1988). Colchester (1998) and Martin (1999) argued that it has alienated local communities from protected areas and resulted in loss of biodiversity, and is thus outdated. Integrated conservation and development, co-management and sustainable use are different concepts, but they all flow from a common ethos that conservation is best (or possibly only) achieved through promoting the welfare

Gert Polet (Corresponding author) WWF-Cat Tien National Park Conservation Project, 2 Phung Khac Khoan Room G15 District 1, Ho Chi Minh City, Vietnam. E-mail gert-ina@wwfhcmc.vnn.vn

Stephen Ling RRAG, RSM Building, Prince Consort Road, Imperial College, London, SW7 2BP, UK.

Received 5 January 2002. Revision requested 27 September 2002. Accepted 5 September 2003. and participation of local people, and proponents of one tend to favour the others. Borrini-Feyerabend (1997) provided a typology on how such management arrangements could work; a continuum from sole responsibility with a single authority (traditional conservation) via comanagement arrangements (participatory conservation) to handing over all responsibility to communities (community-based conservation). Links between people and conservation can take the form of public relations, consultation, deriving benefits, revenue sharing, resource harvesting, participation in management or transfer of management (Clarke, 2000). Those with longstanding experience in conservation management have argued that the traditional approach cannot be regarded as a failure in the way that its critics portray (Spinage, 1999; Atwell, 2000) and they have urged caution in handing protected areas over to communities.

In a review of integrated conservation and development projects, Roe et al. (2000) concluded that the traditional and participatory approaches both have their limitations. Further defusing the debate Adams \& Hulme (2001) argued that the more important questions to ask are 'who should set the objectives for conservation policy?' and 'how should trade-offs between diverse objectives of different interests be negotiated?' We will refer to the general question of the level of local involvement that is appropriate in protected areas as the 
community-based management debate. Evaluation and redesign of conservation practice are indispensable but the sometimes heated debate, and strong pressure from funding agencies to conform to current orthodoxy, can be unhelpful; conservation planning decisions may be branded as either old-fashioned or innovative by outsiders, confusing conservation managers and possibly inhibiting further action.
Here we do not attempt to expound the universal applicability of any one conservation policy. Rather, we offer a case study to illustrate how management planning decisions in Cat Tien National Park, southern Vietnam (Fig. 1), have been based on the collation of reliable information on the Park's mammal fauna. This study focuses on the Park's mammals, not because planning considerations were based exclusively on this

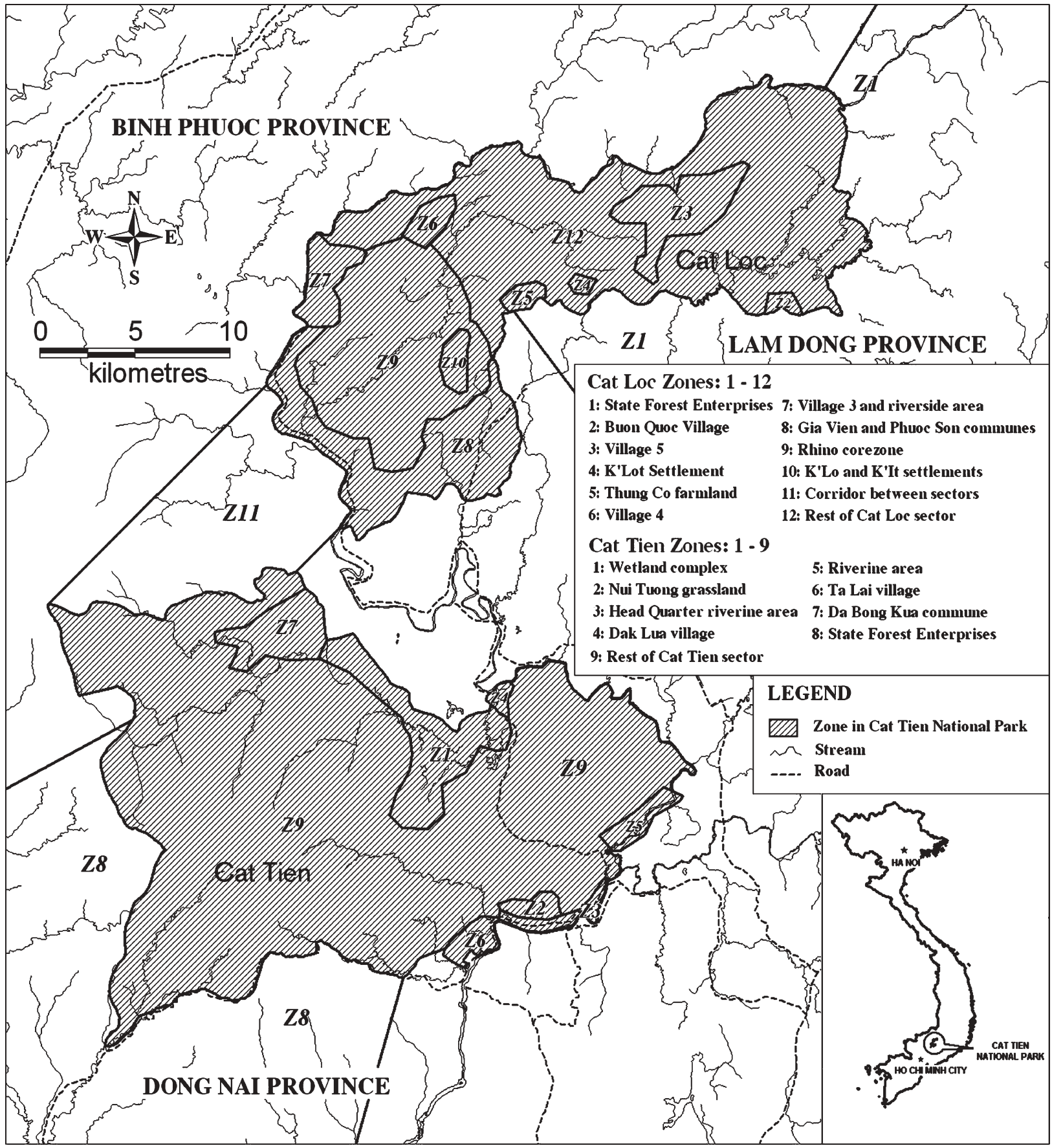

Fig. 1 Conservation Management Zones in Cat Tien National Park and surrounding areas (see text for details), with the shaded areas indicating the northern Cat Loc and southern Cat Tien sections. 
group, but because (1) mammals illustrate general biological properties (diversity, endemism and threat) of conservation importance in the Park, (2) more information is available on the mammals of the Park than on any other group, and (3) large mammals are particularly threatened by the conservation issues facing the Park. We review the Cat Tien National Park mammal fauna, highlight issues facing the species of highest conservation concern, and then link these issues to planning decisions. Finally, we place this case study within the context of the wider community-based management debate.

\section{Cat Tien National Park}

Cat Tien National Park is situated in three Provinces (Fig. 1), c. $150 \mathrm{~km}$ north of Ho Chi Minh City, on the plains of the Dong Nai River. The 73,878 ha Park is divided into two separate sections, Cat Loc in the North and Cat Tien in the South. After being managed separately by the three Provinces since the late 1970s, the areas were integrated in December 1998 and managed by the central government's Ministry of Agriculture and Rural Development.

The topography is characterized by steep low hills and flat areas. The conservation importance of the forests of the Park and its neighbouring state-owned logging concessions (locally known as State Forest Enterprises) is that it is the only remaining example in southern Vietnam of a mosaic of habitats that include sizeable lowland tropical forest ecosystems. The Park was sprayed with herbicides during the Vietnam War (1965-1973) and logged directly afterwards. In areas of dense bamboo and grass cover there is little natural regrowth of trees. Only $50 \%$ of the total area of the Park is classified as evergreen (dominated by Dipterocarpaceae), semi-evergreen (dominated by Lagerstroemia spp.) or mixed forest. Bamboo forest dominates, with $40 \%$ of total land cover. The rest of the area consists of wetlands, grasslands and farmland (FIPI, 1993).

Boundaries are nominally demarcated, within which c. 9,500 people live (CTNP, 2003a), 81\% at the edges of the Park. There are five hamlets located deep inside the Park with a total of 1,774 people). They have no land titles and cannot benefit from governmental or international support but are treated as de facto residents. A large proportion of these people originate from lowland areas that they left after people of the Kinh majority settled in their ancestral lands. Others, however, settled inside the Park after the war as immigrants from other parts of Vietnam. The total population in the 183,479 ha buffer zone, which is heavily farmed and of little conservation value, expanded from 140,987 in 1992 to 188,479 in 2002 (Polet et al., 2003). Part of the boundary is shared with State
Forest Enterprises that have been logged-over but most of them are now under a logging ban. Large parts of these Enterprises have been converted into agricultural lands by illegal settlers, but they also contain large areas of important forest habitat with a variety of wildlife.

\section{Methods}

Information on the mammals of Cat Tien National Park was obtained from technical reports and published articles. Duckworth \& Hedges (1998) described some of the problems related to biodiversity assessments in Vietnam that apply to most of the earlier secondary data available for the Park: 'poor quality fieldwork, unreliable interpretation of village information, weak documentation of findings, plagiarism of findings and falsification of findings'. A provisional list was compiled of all the species mentioned in reports, discarding the most obvious errors. Species for which photographic or video material is available, or that specialists have sighted recently, were categorized as 'confirmed'. Species that were mentioned in just one recent or several dated reports and/or without providing clear evidence, were categorized as 'possible'.

Biological surveys have been carried out since the early 1990s in the areas that now comprise the Park. Some were highly focused and structured, others were largely opportunistic. In general these surveys lasted several weeks and included standard methodologies such as direct observations, capturing of specimens, interpretation of signs and discussions with local people. The first major biodiversity inventory was undertaken in 1993 by the semi-governmental Forest Inventory and Planning Institute (FIPI, 1993) and included a listing of mammal species. The Institute of Ecology and Biological Resources reported extensively on the Park's fauna (Le Xuan Canh et al., 1998). These two pieces of earlier work were, however, based mainly on interviews rather than field records. In 2001 the Institute of Ecology and Biological Resources and the Vietnam-Russia Tropical Centre conducted general biodiversity surveys (IEBR, 2001; VRTC, 2002). A survey of bats was conducted in 1998 (Cao Van Sung et al., 2000), but most of the mammal survey work that has been carried out targeted high profile groups: elephants (Dawson et al., 1993; Sukumar et al., 2002), rhinoceros (Schaller et al., 1990; Haryono et al., 1993; Cao Van Sung et al., 1998; Polet et al., 1999), wild cattle (Ling, 2000) and primates (Eames \& Robson, 1993). Ling (2000) was able to confirm a large number of species on the provisional mammal list, and standardized naming following Corbet \& Hill (1992). Since 2000, visiting naturalists have recorded their mammal observations in a logbook (Murphy, 2001). These have been valuable in establishing the presence of several species. 
Further records of species' occurrence were obtained with the aid of automatic phototraps (TrailMaster TM 1550) that have been in use since 1999.

Human population data were obtained from the 2000 National Population Census. Socioeconomic activities were assessed through semi-structured rapid appraisals. Sizes of farmed areas were obtained through governmental land title files and cross-checked for location using Landsat 5 TM (124/052) and Spot HRV (277/327) satellite images for 1995.

This information on biodiversity, key species, human population and conflicts was used to divide the Park and its surrounding areas into 21 management zones (Fig. 1): 10 zones within the Cat Loc sector of the Park, eight within the Cat Tien sector, one between the two sectors, and two zones adjacent to each sector comprising State Forest Enterprises (largely redundant state-owned logging concessions containing forest in varying degrees of intactness). These zones were chosen to encompass individual villages within the Park's boundaries, known ranges of the most important species, or important habitats such as the Crocodile Lake wetland complex. For each zone conservation value was evaluated against current socioeconomic activities, making use of secondary data and additional information from Park staff and local people. Management recommendations were then formulated for each zone, incorporating the views and aspirations of the people living in those zones.

\section{The mammals of Cat Tien National Park}

A total of 76 species of mammal are known to occur in the Park (Appendix) and there is evidence for the presence of at least another 32. Sixteen of the confirmed species are globally threatened (IUCN, 2003), and possibly a further 11 (Table 1). Bats and murids are the most diverse mammal groups, but have been little studied. Excluding these, 38 species of larger mammals have been confirmed, and at least another 13 are possibly present.

Table 1 Total number* of species recorded for five taxa in Cat Tien National Park, with percentage of Vietnam total, and number categorized as threatened on the 2003 IUCN Red List (IUCN, 2003).

\begin{tabular}{lcll}
\hline Taxa & $\begin{array}{l}\text { Number of } \\
\text { species }\end{array}$ & $\begin{array}{l}\text { \% of Vietnam } \\
\text { total }\end{array}$ & $\begin{array}{l}\text { 2003 IUCN } \\
\text { Red List }\end{array}$ \\
\hline Mammals & $76(108)$ & $30(43)$ & $16(27)$ \\
Birds & $321(339)$ & $37(40)$ & $15(16)$ \\
Reptiles & $73(84)$ & $27(31)$ & $8(8)$ \\
Amphibians & $35(39)$ & $29(38)$ & 0 \\
Freshwater fish & $99(130)$ & $21(28)$ & 1 \\
Butterflies & $435(439)$ & $43(44)$ & 0 \\
\hline
\end{tabular}

*Non-bracketed figures are confirmed records; figures in parentheses include possible records.
The Park contains a high diversity of species compared to other protected areas in Vietnam (Eve, 1999, on Vu Quang Nature Reserve; SFNC, 2000, on Pu Mat Nature Reserve), especially for a relatively small area with a limited altitudinal range, with $30 \%$ of Vietnam's known mammal species (43\% if additional 'possible' species are included). The Park's high biodiversity is due to its location in a transitional zone between the biogeographically distinct Dalat Plateau and the Mekong Delta. The occurrence of species endemic to Indochina (Laos, Cambodia and Vietnam) further illustrates the area's outstanding importance: northern smooth-tailed tree shrew Dendrogale murina, black-shanked douc langur Pygathrix nigripes, lesser slow loris Nycticebus pygmaeus and yellow-cheeked crested gibbon Hylobates gabriellae. Endemism amongst murids is believed to be higher.

Thirty-four bat species have been recorded in the Park and another two require confirmation. Eudiscopus denticulus is the first record for Vietnam (VRTC, 2002). The primate community includes three species of native macaques, two langurs, one gibbon and one loris. Captive-bred rhesus macaque Macaca mulatta were erroneously released in 1999; they are breeding prolifically and are in direct competition and are also interbreeding with native crab-eating macaque Macaca fascicularis. Black-shanked douc langurs and yellow-cheeked crested gibbons are heard and seen regularly throughout the Park but do not occur at high densities; their status is poorly known (Adler, 1990; Eames \& Robson, 1993). Silvered leaf monkey Trachypithecus cristatus has been confirmed in small numbers. Langurs and gibbons require high quality forest, and their numbers could be limited by the reduction and fragmentation of mature forests in the Park (Eames \& Robson, 1993).

The only large carnivore whose presence is confirmed is the sun bear Helarctos malayanus, and of the five possible species of cats only leopard cat Prionailurus bengalensis is confirmed. If large carnivores do survive in the area, then it is only in small and probably non-viable numbers. Despite relatively high prey densities, the Park is not able to sustain viable large carnivore populations in isolation from its surrounding forests. Eleven small carnivore species are confirmed and an additional five species possibly occur in the Park.

Densities of several of the smaller ungulates are generally high. Signs and sightings of sambar Cervus unicolor, Eurasian wild pig Sus scrofa, Indian muntjac Muntiacus muntjak and lesser Malay mouse deer Tragulus javanicus are common (Ling, 2000; Murphy, 2001). Several herds of gaur Bos gaurus occur in the Park as well as in neighbouring State Forest Enterprises (Ling, 2000). They depend on grasslands for feeding and forest for shelter, and both these habitats are available within the Park and the wider landscape. There are reports that banteng Bos javanicus 
and wild water buffalo Bubalus arnee may still survive in the southern sector (Dawson et al., 1993, Ling, 2000; Murphy, 2001).

Both Critically Endangered Asian elephant Elephas maximus and Javan rhinoceros Rhinoceros sondaicus annamiticus occur in the Park. Elephants are restricted to the southern section and make extensive use of remaining habitat in the State Forest Enterprises bordering the Park (Polet \& Pham Huu Khanh, 1999). Over the last 4 years elephants have started to come into conflict with people who encroach onto the elephant range outside the Park. Sukumar et al. (2002) estimated that the Park contains 10-17 elephants, including two calves, but the habitat inside the Park alone cannot support a viable population, having the potential to hold only c. 40 elephants (Sukumar et al., 2002). Javan rhinoceros Rhinoceros sondaicus is one of the world's rarest large mammals, with only two populations, representing different subspecies: $R$. sondaicus sondaicus (50-60 individuals) in Ujung Kulon National Park, Java, Indonesia, and $R$. sondaicus annamiticus in Cat Tien National Park. The number of animals has declined from an estimated 10-15 (Schaller et al., 1990) in 1989 to the current population of 5-8, confined in an area of 5,100 ha of sub-optimal habitat, dominated by bamboo and rattan. The animals are presently isolated from important riparian habitats and salt licks, which have been converted into agricultural fields. Apart from one confirmed female, the age and sex structure of the group is unknown (Polet et al., 1999; AsRSG, 2000). The protection of rhinos has improved considerably since 1998, but poaching, disturbance and disease are a continuing threat. A string of villages within the Park confine the rhinos to a fraction of the available habitat (CTNP, 2000; AsRSG, 2000).

Several small diurnal mammals have been recorded, but the group is dominated numerically by a single species of tree squirrel (Callosciurus erythraeus). Seven other species of squirrels and tree shrews occur, including the Indian giant flying squirrel Petaurista philippensis, a distinctive subspecies of black giant squirrel Ratufa bicolor smithi and northern smooth-tailed tree shrew. The latter two species have relatively narrow world ranges. Burmese hare Lepus peguensis and East Asian porcupine Hystrix brachyura are numerous and may be an important part of the prey base for carnivores.

\section{Threats to the Park and its mammals}

Until the late 1990s conservation management of the Park was only partly effective. Poor commitment to conservation at decision-making levels resulted in a significant immigration of people, heavy encroachment on the Park's fringes, illegal logging and poaching. The last Javan rhino sign encountered in the Cat Tien sector was in 1988 (Schaller et al., 1990). Siamese crocodile Crocodylus siamensis was last observed in 1996 (Bembrick \& Canon, 1999) but successfully re-established in 2001 (Polet et al., 2002). In the late 1990s the conservation situation improved when Government and international donors started to provide infrastructure, equipment and training, and biological and socioeconomic research commenced. The Park, as the implementing agency for community development activities in the buffer zone, established active ties with the surrounding communities, and gained their respect.

Nevertheless, conservation problems remain, with a number of current threats (Table 2). Boundaries are not clearly demarcated and encroachment continues. The five villages located deep inside the Park, with their associated fields and roads, pose a threat to biodiversity by disturbance of wildlife, forest clearance, opportunistic poaching, and by breaking up habitat blocks and thus restricting movement of wildlife. Domestic livestock within the Park pose a risk of disease spread into wild populations.

Violations of the Park's rules are numerous (Fig. 2), but Park authorities estimate that only about $10 \%$ of the violations are detected (Tran Van Thanh, pers. comm.). Hunting and fishing pose a direct threat to all remaining wildlife, although high profile species such as elephants and rhinoceros are not targeted. Poaching seems to be related more to growing economic wealth in the cities rather than to poverty of households in the Park's vicinity (pers. obs.). Violations appear to have generally been on the increase since 1990 (Fig. 2) despite a substantial improvement in the socioeconomic status of people in the vicinity of the Park.

\section{Conservation management planning}

A conservation management planning process has been initiated at three levels. Firstly, the most pressing problem (the large human population within the Park) is being resolved. Secondly, lesser conservation issues were addressed in a new conservation management and operational plan. Thirdly, steps were undertaken to address conservation in the wider landscape. The key considerations for management planning were: (1) High mammalian biodiversity, with a number of individual populations of global importance requiring expansion of the habitat available to them. (2) A relatively large human population surrounding the Park, with the majority practising intensive agriculture, and only a small group depending on the Park for a significant proportion of their resources. (3) Most wild resources taken from the Park are traded to supply urban markets, but few of these resources are considered able to withstand a harvest regime. (4) Although a few abundant resources, such as fish and grasses, could be sustainably harvested, 
Table 2 Threat assessment and management responses in Cat Tien National Park, after Polet \& Tran Van Mui (2003).

\begin{tabular}{|c|c|c|c|}
\hline \multirow[b]{2}{*}{ Threat } & \multicolumn{2}{|c|}{ Threat Level (1-5) } & \multirow[b]{2}{*}{ Management action } \\
\hline & Current & Potential & \\
\hline Human population deep inside Park & 4 & 5 & 1. Resettlement of 691 people \\
\hline $\begin{array}{l}\text { Human population inside Park but at edges, } \\
\text { resulting in encroachment }\end{array}$ & 3 & 5 & $\begin{array}{l}\text { 1. Excise populated edge areas }(7,926 \mathrm{ha}) \text { from } \\
\text { Park by re-demarcation of boundaries so that } 7,655 \\
\text { people will be outside the Park without having to resettle }\end{array}$ \\
\hline Poaching for urban market & 3 & 5 & $\begin{array}{l}\text { 1. Strict law enforcement within Park } \\
\text { 2. Support Forest Protection Departments in urban areas } \\
\text { to suppress illegal wildlife trade } \\
\text { 3. Mass conservation education programmes (especially } \\
\text { television) to change cultural attitudes }\end{array}$ \\
\hline $\begin{array}{l}\text { Poaching, tree cutting, rattan harvesting } \\
\text { for own consumption (rare species) }\end{array}$ & 3 & 5 & $\begin{array}{l}\text { 1. Strict law enforcement within Park boundaries } \\
\text { 2. Conservation education in buffer zones } \\
\text { 3. Community development activities providing } \\
\text { alternative livelihoods }\end{array}$ \\
\hline Collecting bamboo, fishing (common species) & 2 & 3 & $\begin{array}{l}\text { 1. Seek co-management options with local communities } \\
\text { /allow a limited off take in return for respecting other } \\
\text { Park regulations }\end{array}$ \\
\hline $\begin{array}{l}\text { Grazing of domestic livestock within Park } \\
\text { posing threat to health of wild herbivore } \\
\text { and pheasant species }\end{array}$ & 3 & 4 & $\begin{array}{l}\text { 1. Strict law enforcement } \\
\text { 2. Improve demarcation of boundaries }\end{array}$ \\
\hline Encroachment of invasive alien species & 2 & 3 & $\begin{array}{l}\text { 1. Eradicate Mimosa pigra in wetlands } \\
\text { 2. Suppress floating grass in wetlands }\end{array}$ \\
\hline $\begin{array}{l}\text { Ageing grasslands posing wild-fire } \\
\text { risk and unpalatable for wild herbivores }\end{array}$ & 2 & 3 & $\begin{array}{l}\text { 1. Cut old stands of grass \& burn residue } \\
\text { 2. Explore possibilities for control burning of grasslands }\end{array}$ \\
\hline Wild fires & 2 & 2 & 1. Strict fire protection \\
\hline $\begin{array}{l}\text { Uncontrolled tourism development resulting } \\
\text { in littering and noise problems }\end{array}$ & 2 & 3 & $\begin{array}{l}\text { 1. Formulate and implement a sustainable tourism } \\
\text { management plan that zones the Park in intensive and } \\
\text { restricted tourism zones, limitation on number of visitors } \\
\text { 2. Strict littering control } \\
\text { 3. Strict noise control }\end{array}$ \\
\hline $\begin{array}{l}\text { Isolation of Park leads to erosion of } \\
\text { conservation values (especially loss of } \\
\text { large mammals in long-term) }\end{array}$ & 3 & 4 & $\begin{array}{l}\text { 1. Explore possibilities to change management } \\
\text { regime of neighbouring State Forest Enterprises in order } \\
\text { to gain a conservation function within them or to convert } \\
\text { them into protected areas }\end{array}$ \\
\hline $\begin{array}{l}\text { Limited or no governmental budgets } \\
\text { for standard maintenance operations }\end{array}$ & 2 & 4 & $\begin{array}{l}\text { 1. Insist that Government provides funds for standard } \\
\text { maintenance operations on buildings, trails, control of } \\
\text { invasive species, etc. } \\
\text { 2. Seek to include above in standard Governmental } \\
\text { Investment Plans for protected areas, formulated by the } \\
\text { Forest Inventory and Planning Institute, which are } \\
\text { currently biased to infrastructural development and that } \\
\text { seldom include activities that address recognized threats } \\
\text { to conservation }\end{array}$ \\
\hline $\begin{array}{l}\text { Poor coordination between Government } \\
\text { Departments within and between different } \\
\text { governmental levels }\end{array}$ & 2 & 2 & $\begin{array}{l}\text { 1. Insist that Park has a land use function in the wider } \\
\text { region while initiating improvements in coordination } \\
\text { between different Departments and different } \\
\text { Governmental levels }\end{array}$ \\
\hline
\end{tabular}

Vietnam Government regulations do not allow any offtake from protected areas. Decision 8 (Government of Vietnam, 2001), that operationalizes the Law on Forest Protection and Development (1991), stipulates that stakeholders other than the Government appointed management boards cannot take part in making management decisions and that all extractive and most non-extractive uses are not allowed in protected areas. (5) Even if there were no legal obstacles, co-management regimes might function poorly in Vietnam where responsible authorities have limited capacity, and communities are large in number and appear to have limited discipline to manage complex arrangements. Management responsibility in the hands of either an authority or the community fits the Vietnamese experience best. Development opportunities for communities residing inside the Park are thus severely restricted from a biological and legal point of view. 


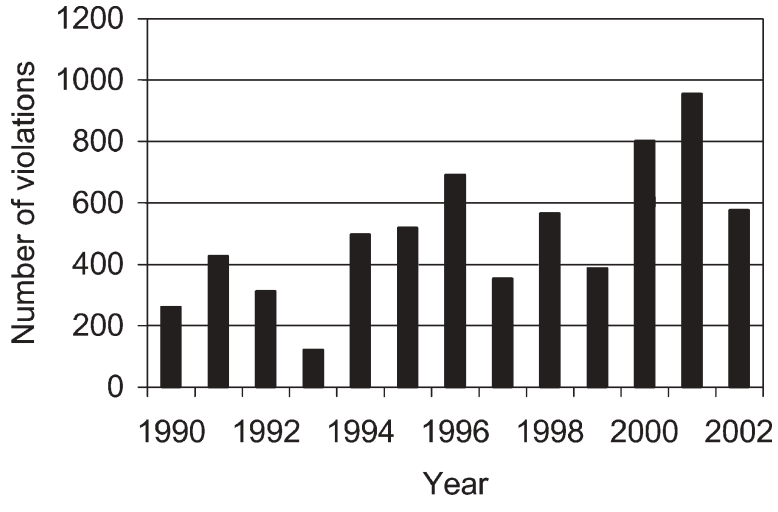

Fig. 2 Number of detected violations of conservation laws between 1990 and 2002 in Cat Tien National Park.

Twenty-one management zones (Fig. 1) were defined for the Park. For each zone biodiversity values and socio-economic activities were described and evaluated against each other (Table 3), using both existing data and information from some additional fieldwork. Throughout the process a dialogue was maintained with local communities, seeking additional ecological information and inputs into the review of conservation management recommendations. People's views and aspirations were thus incorporated into decisions, ensuring that they were acceptable, and creating essential support for implementation. To improve the viability of the Park, two interventions were agreed: boundary re-demarcation and resettlement of isolated hamlets (CTNP, 2000). The first priority is to redefine the Park's boundaries to excise the heavily populated areas on the fringes, reducing the area of the Park by $10 \%$, so that $81 \%$ of people currently living within the Park will not require resettlement. They will be placed under the Commune authorities and will become eligible for land titles and other support, thus enhancing their economic status. Agricultural land remaining within the Park will be compensated for and left to regenerate. Recognizing that development prospects are nonexistent, 691 people in isolated villages have indicated that they wish to be resettled outside the Park. One village, with 1,083 people, will remain within the Park as an enclave, as it was deemed too large and costly for resettlement. The details have been agreed at different government levels and with the affected people (CTNP, 2003a), and the government has committed $c$. US $\$ 3$ million for implementation.

Although Cat Tien National Park has an approved Investment Plan, it is concerned mainly with investment in infrastructure and does not identify threats to biodiversity or formulate mitigating conservation management activities. A new conservation management plan was therefore formulated for the less pressing conservation issues (CTNP, 2003b). Based on the national legal framework and consultations with local communities, the Park's objectives have been formulated, and include preservation, research and tourism. A further objective is to assist communities living in the buffer zone to improve their living conditions, with the Park to act as a catalyst to secure Vietnam Government and foreign investment. The management plan addresses both site- and species-specific threats, and interventions in ecological processes. The latter include the eradication of invasive alien species such as Mimosa pigra, interventions in ecological succession (such as the control of floating vegetation in a shallow lake), and controlled burning to prevent wild fires and to provide improved grazing for large ungulates. There is a proposal that will allow the sustainable harvest of several abundant resources (such as fish, and bamboo and grasses for thatch and feeding to domestic cattle) in return for commitments to leave high value species undisturbed. Legal obstacles have to be overcome, however, before these co-management approaches can be implemented within the Park.

As the Park's larger mammals cannot be maintained if the Park remains managed in isolation from neighbouring forests, steps are being undertaken to secure ecological linkages within the wider landscape. Important forest blocks remain in six protected areas and 39 State Forest Enterprises in the south-east Vietnam agro-ecological zone, and the Park itself is directly bordered by five of these Enterprises. These contain regenerating forest but do not have an official wildlife protection function. Other areas are de facto occupied by people who have no land titles and thus no security. A plan is being completed to turn areas of conservation importance in three of these Enterprises into a protected area contiguous with the Park, and to excise agricultural land and provide the operators with legal titles. A similar approach is being taken in other State Forest Enterprises, seeking to secure biodiversity conservation in a network of existing and new protected areas linked together by State Forest Enterprises.

\section{Discussion}

Management planning in Cat Tien National Park has not followed a particular conservation dogma, but sought pragmatic solutions based on available biological and socioeconomic information and within the legal framework. Different conservation management approaches are being pursued in different locations. Within the Park a traditional approach is enforced. Decision making remains in the hands of the responsible authority, which engages local communities by sharing information and carrying out consultations for management planning 

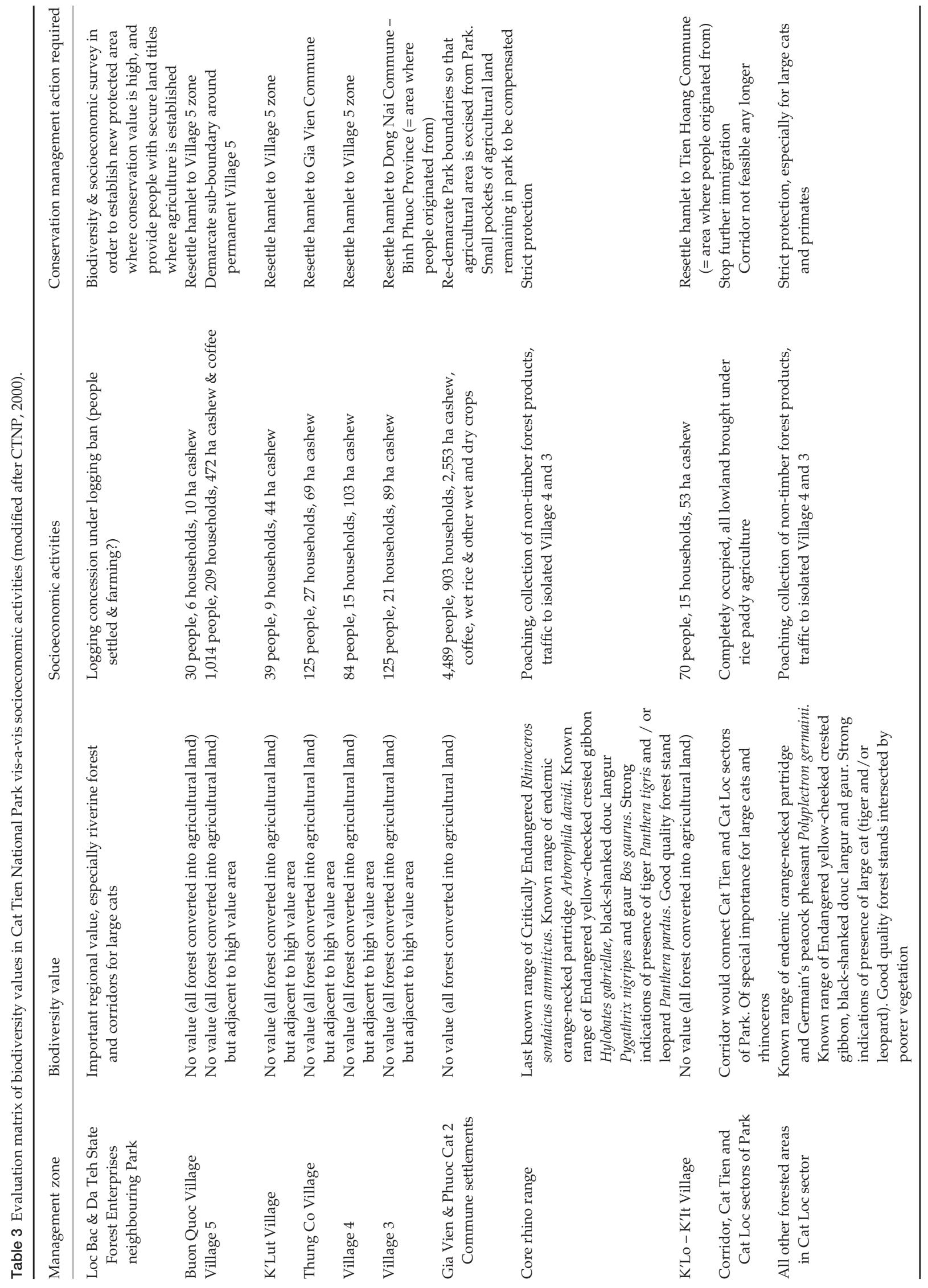


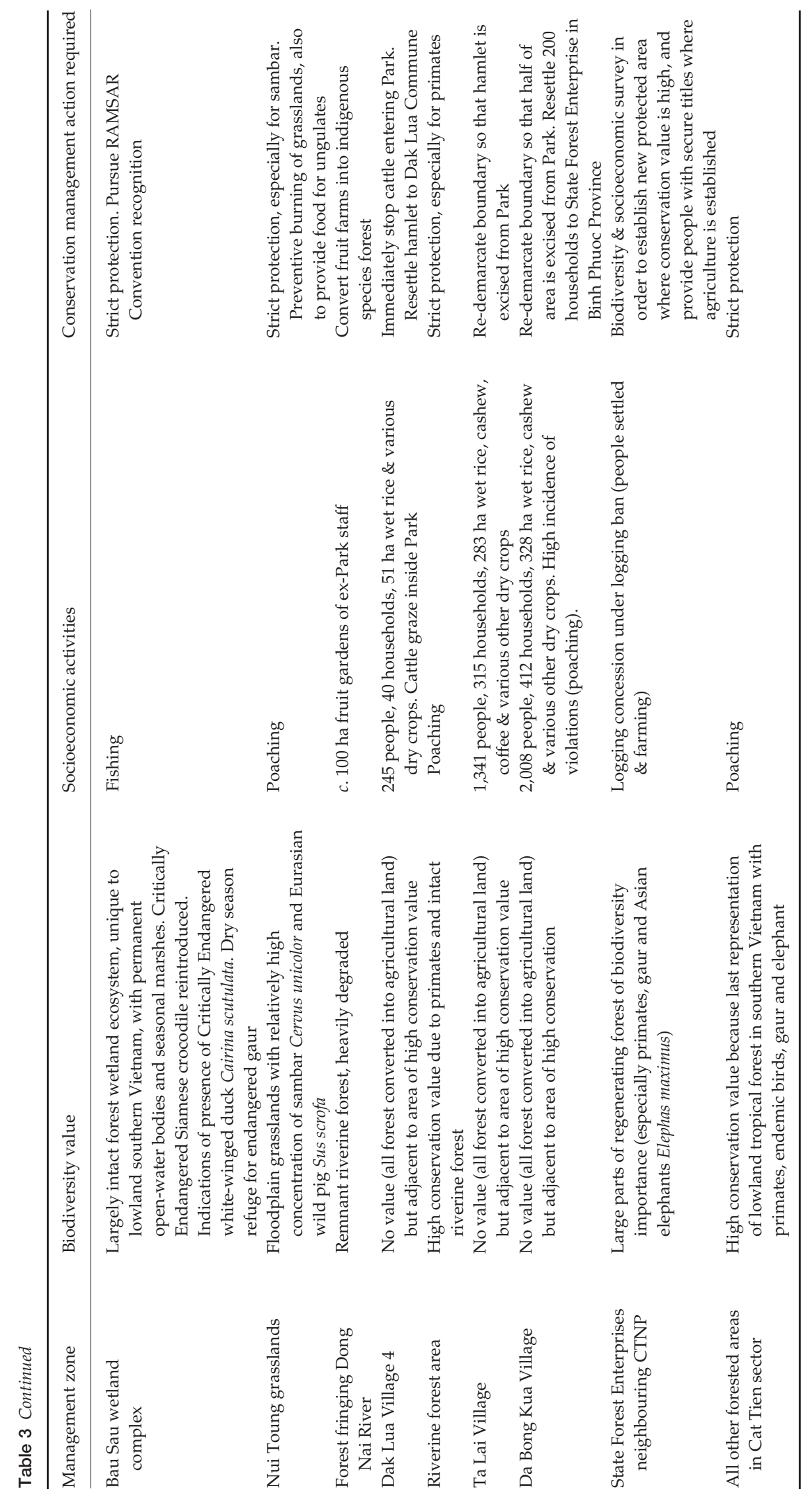


processes. In South-east Asia, where many small protected areas are surrounded by dense human populations practising intensive agriculture, this approach is often the most realistic way of achieving conservation of threatened biodiversity. A clear geographical separation of conservation and development land uses works best within the Vietnamese legal framework and culture of authority (Polet et al., 1999; Polet, 2003). A more participatory approach in which local communities share benefits, such as tourism, and sustainable harvesting of certain resources, will be tried within the Park on an experimental basis.

Legislation does not, however, allow local communities to participate in management decision-making for protected areas. The legal framework is, however, less constraining in State Forest Enterprises, and hence in the wider landscape community-based conservation approaches are possible. A suite of options are being pursued to engage local communities to varying degrees: converting State Forest Enterprises that have important biodiversity values into protected areas, establishing wildlife protection agendas for State Forest Enterprises, establishing community-operated forests for sustainable harvesting of timber and non-timber forest products, and handing over State Forest Enterprises that are already converted into agricultural land to local communities. It is hoped that a net conservation benefit will be achieved, in which Cat Tien National Park is embedded in a network of natural and semi-natural habitats.

Traditional management approaches for protected areas have their limitations but have also proven their effectiveness in protecting important biodiversity values. Community-based conservation management approaches may provide new opportunities but their limitations need to be recognized. Roe et al. (2000) concluded that '. . . the old is not yet invalid and the new has not been coherently argued, much less proven'. Instead of tying the hands of conservation managers to the fashionable conservation management approach of the moment, it is the responsibility of conservation managers to apply these approaches wisely at different geographical locations, based on sound scientific information and taking into consideration both the legal framework and the aspirations of local people, so that pragmatic decisions are made. Our experience in Cat Tien National Park suggests that conservation and development cannot both be prioritized in a single location, but having the flexibility to assign different approaches to different areas may provide a solution beneficial to all.

\section{Acknowledgements}

We would like to thank Bui Huu Manh for preparing the map. Two anonymous reviewers are thanked for their thorough work and good suggestions.

\section{References}

Adams, W.M. \& Hulme, D. (2001) If community conservation is the answer in Africa, what is the question? Oryx, 35, 193-200.

Adler H.J. (1990) The Crested Gibbon, Hylobates (Nomascus) concolor [Harlan, 1826] in the Nam Cat Tien Reserve, South Vietnam. Garrulax, 7, 6-10.

AsRSG (Asian Rhino Specialist Group) (2000) Action Plan 2000/2010 for the Preservation of the Vietnamese Rhino in Cat Tien National Park, Vietnam. IUCN, Gland, Switzerland.

Attwell, C.A.M. (2000) What if the emperor has no clothes? A reply to Martin. Oryx, 34, 3-7.

Bembrick, J. \& Cannon, Z. (1999) A Report on the Siamese Crocodile, Crocodylus siamensis, in Cat Tien National Park. Technical Report No. 1 for WWF, Cat Tien National Park Conservation Project, Vietnam.

Borrini-Feyerabend, G. (ed.) (1997) Beyond Fences: Seeking Social Sustainability in Conservation. IUCN, Gland, Switzerland.

Cao Van Sung, Dang Huy Huynh, Nguyen Xuan Dang, Le Xuan Canh, Pham Mong Giao \& Van Strien, N. (1998) A Report on the Results of Training and Field Survey of Javan Rhinoceros in Cat Loc Nature Reserve (South Vietnam), April-May 1998. Unpublished Report. WWF Indochina Programme, Hanoi, Vietnam.

Cao Van Sung, Eger, J. \& Ngo Van Tri (2000) Ket Qua Buoc Dau Sat Doi o Mien Nam Vietnam [Preliminary survey of bats in South Vietnam]. Journal of Biology, March 2000, 136-144.

CTNP (Cat Tien National Park) (2000) Conservation Management Plan. Unpublished Report. Cat Tien National Park Management Board, Dong Nai Province, Vietnam. CTNP (Cat Tien National Park) (2003a) Framework for the Integrated Boundary Re-demarcation and Resettlement Action Plan, Cat Tien National Park. Unpublished Report. Cat Tien National Park Management Board, Dong Nai Province, Vietnam

CTNP (Cat Tien National Park) (2003b) Conservation Management and Operational Plan for Cat Tien National Park. Unpublished Report. Cat Tien National Park Management Board, Dong Nai Province, Vietnam.

Clarke, J.E. (2000) Protected area management planning. Oryx, 34, 3-7.

Colchester, M. (1998) Who will garrison the fortress? A reply to Spinage. Oryx , 32, 245-247.

Corbert, G.B. \& Hill, J.E. (1992) The Mammals of the Indomalayan Region: A Systematic Review. Natural History Museum Publications, Oxford University Press, UK.

Dawson, S., Do Tuoc, Le Vu Khoi \& Trinh Viet Cuong (1993) Elephant Surveys in Vietnam. Unpublished Report. WWF Vietnam Programme, Hanoi,Vietnam.

Duckworth, J.W. \& Hedges S. (1998) A Review of the Status of Tiger, Asian Elephant, Gaur and Banteng in Vietnam, Lao, Cambodia and Yunnan Province (China), with Recommendations for Future Conservation Action. WWF Indochina Programme, Hanoi, Vietnam.

Eames, J.C. \& Robson, C.R. (1993) Threatened Primates in Southern Vietnam. Oryx, 27, 146-154.

Eve, R. (1999) Vu Quang Nature Reserve Management Plan. Unpublished Report. WWF Indochina Programme, Hanoi, Vietnam.

FIPI (Forest Inventory and Planning Institute) (1993) Luan Chung Kinh te ky thuat VQG Cat Tien [Feasibility Study of Cat Tien National Park]. Unpublished Report. Forest Inventory and Planning Institute Hanoi, Vietnam. 
Government of Vietnam (2001) Decision No. 08/QD-TTg on the Management of Special Use Forest Protection Forest and Production Forest, 11 January 2001. Hanoi, Vietnam.

Haryono, M., Jito Sugarjito, Pham Mong Giao, Vu Van Dung \& Nguyen Xuan Dang (1993) Report of Javan Rhino (Rhinoceros sondaicus) Survey in Vietnam. Technical report to WWF, Hanoi, Vietnam

Indamar, A., de Jode, H., Lindsay, K. \& Cobb, S. (1999) Capitalizing on nature: protected area management. Science, 283(5409), 1856-1857.

IEBR (Institute of Ecology and Biological Resources) (2001) Bao Cao Ket Qua dieu tra xay dung danh luc dong vat hoang da (thu, chim, bo sat, ech nhai) o Vuon Quoc Gia Cat Tien [Report on Surveys for Preparing Lists of Animals (Mammals, Birds, Reptiles, Amphibians) in Cat Tien National Park]. Unpublished Report. Institute of Ecology and Biological Resources, Hanoi, Vietnam.

IUCN (2003) 2003 IUCN Red List of Threatened Species. IUCN, Gland, Switzerland \& Cambridge, UK

[http:/ / www.redlist.org, accessed 24 February 2004].

Leader-Williams, N. \& Albon, S. (1988) Allocation of resources for conservation. Nature, 336, 353.

Le Xuan Canh, Hoang Minh Khien, Le Ding Thuy, Ho Thu Cuc, Hoang Vu Tru, Nguyen Van Tri, Nguyen Tran Vy \& Tran Viet Dung (1998) Bao cao ket qua dieu tra khu he dong vat tai KBTTN Cat Loc, Huyen Cat Tien, Tinh Lam Dong [Results of Zoological Survey in Cat Loc Nature Reserve, Cat Tien District, Lam Dong Province]. Unpublished Report. Institute of Ecology and Biological Resources, Hanoi, Vietnam.

Ling, S. (2000) A Survey of Wild Cattle and Other Mammals, Cat Tien National Park - Vietnam. Technical Report No. 14, WWF - Cat Tien National Park Conservation Project, Vietnam.

Martin, R.B. (1999) The rule of law and African game, and social change and conservation misinterpretation; a reply to Spinage. Oryx, 33, 89-94.

Murphy, D. (2001) Mammal Observations in Cat Tien National Park, Vietnam 2000-2001. Technical Report No. 35, WWF Cat Tien National Park Conservation Project, Vietnam.

Polet, G. (2003) Co-management in protected area management; the case of Cat Tien National Park - southern Vietnam. In Co-management of Natural Resources in Asia: A Comparative Perspective (eds G.A. Persoon, D.M.E. van Est \& P.E. Sajise), pp. 25-42. Nordic Institute of Asian Studies, Man \& Nature in Asia series No. 7, Copenhagen, Denmark.

Polet, G., Do Van Dat \& Nguyen Van Chau (2003) Monitoring and Evaluation of Human Populations in the Buffer Zone of Cat Tien National Park Vietnam, 1992-2002. Technical Report No. 45, WWF - Cat Tien National Park Conservation Project, Vietnam.

Polet, G., Murphy, D. J., Phan Viet Lam \& Tran Van Mui (2002) Crocodile conservation at work in Vietnam, re-establishing Crocodylus siamensis in Cat Tien National Park. In Crocodiles. Proceedings of the 16th working meeting of the Crocodile Specialist Group, pp. 86-95. IUCN, Gland, Switzerland and Cambridge, UK.

Polet, G. \& Pham Huu Khanh (1999) On the Asian Elephants of Cat Tien National Park, Vietnam. In Proceedings of the Conference Conservation of the Asian Elephant in Indochina (eds L. Osborn \& M. Vinton), pp. 40-45. Fauna \& Flora International, Hanoi, Vietnam.
Polet, G. \& Tran Van Mui (2003) Cat Tien National Park, Vietnam. In Capacity Needs to Manage Protected Areas Asia (eds Julia Carabias \& Kishore Rao), pp. 129-138.

The Nature Conservancy, Arlington, USA.

Polet, G., Tran Van Mui, Nguyen Xuan Dang, Bui Huu Manh \& Baltzer, M. (1999) The Javan Rhinoceros, Rhinoceros sondiacus annamiticus, of Cat Tien National Park, Vietnam: Current status and management implications. Pachyderm, 27, 34-48.

Roe, D., Mayers, J., Grieg-Gran, M., Kothari, A. \& Fabricius, C. (2000) Evaluating Eden: Exploring the Myths and Realities of Community-based Wildlife Management. IIED Evaluating Eden Series No. 8, London, UK.

Schaller, G.B., Nguyen Xuan Dang, Le Dinh Thuy \& Vo Thanh Son (1990) Javan Rhinoceros in Vietnam. Oryx, 24, 77-80.

SFNC (Social Forestry and Nature Conservation) (2000) $P u$ Mat: A Biodiversity Survey of A Vietnamese Protected Area. Unpublished Report. European Union, Vinh, Vietnam.

Spinage, C. (1998) Social change and conservation misrepresentation in Africa. Oryx, 32, 265-276.

Spinage, C. (1999) A reply to Martin. Oryx, 33, 281-284.

Sukumar, R., Varma, S. \& Nguyen Xuan Dang (2002) The Status and Conservation of Asian Elephants in Cat Tien National Park, Vietnam. Technical Report, WWF - Cat Tien National Park Conservation Project, Vietnam.

VRTC (Vietnam-Russian Tropical Centre) (2002) Results of Complex Zoological - Botanical Expedition in Cat Loc - Cat Tien National Park Vietnam. Technical Report No. 36, WWF - Cat Tien National Park Conservation Project, Vietnam.

Wells, M., Brandon, K. \& Hannah, L (1992) People and Parks: Linking Protected Area Management with Local Communities. The World Bank, Washington, DC, USA.

\section{Appendix}

The appendix for this article is available online at http: / / journals.cambridge.org

\section{Biographical sketches}

Gert Polet has been interested in human-wildlife interactions ever since his masters study in Chobe-Botswana in 1998. As a technical adviser he has been seeking to gain conservation benefits and foster community development in different manners in different protected areas in Tanzania, the Philippines, Nigeria and Vietnam by taking into account specific local circumstances.

Stephen Ling studied large mammals in Cat Tien National Park and assisted with the formulation of its conservation management plan. He has worked in Indochina on wildlife surveys, protected area management and staff training. Currently he is working in the Tien Shan mountains of Central Asia, applying bio-economic models to hunting, and developing rational frameworks for designing conservation interventions according to local circumstances. 